\title{
GHEORGHE MÂRZESCU ȘI VOCAȚIA LIBERTĂȚII. DESPRE UN PROFESOR UITAT AL FACULTĂȚII DE DREPT DIN IAȘI
}

DOI: 10.24193/SUBBiur.65(2020).4.15 Data publicării online:

\section{Dan Constantin MÂṬ̆ $\breve{A}^{*}$}

\begin{abstract}
Rezumat: Contribuția profesorului Gheorghe Mârzescu la dezvoltarea învățământului juridic la Universitatea din Iași este esențială. Jurist de formație franceză, acesta s-a implicat, de o manieră activă, la consolidarea instituțională și a activității didactice la Facultatea de Drept în primii săi ani de funcționare Faptul că, pentru o lungă perioadă de timp, nu a avut calitatea de profesor ne demonstrează contextul dificil în care se aflau studiile juridice la Universitatea din Iași. Grație operelor sale, Gheorghe Mârzescu s-a făcut remarcat ca fondatorul studiului științific al dreptului civil la Iași. A fost adeptul valorilor liberale și un promotor constant al principiului laicizării, motiv pentru care a intrat în conflict direct cu reprezentanții Bisericii. În ciuda complexității lor, viața și opera profesorului Gheorghe Mârzescu sunt, actualmente, prea puțin cunoscute. El este adesea confundat cu fiul său, important om politic la începutul peiroadei interbelice. Prezentul articol își propune să scoată în lumină o parte a valențelor complexe ale acestei personalități și să insiste asupra rolului său fondator și a vocației libertății pe care a promovat-o în permanență.
\end{abstract}

* Conf. univ. dr., Facultatea de Drept, Universitatea „Alexandru Ioan Cuza” din Iaşi, danmata@uaic.ro. 

academică.

Cuvinte cheie: istoria învățământului juridic, drept civil, personalitate

\author{
GHEORGHE MÂRZESCU AND THE VOCATION \\ OF FREEDOM. \\ ABOUT A FORGOTTEN PROFESSOR OF THE \\ FACULTY OF LAW FROM IAȘI
}

\begin{abstract}
Professor Gheorghe Mârzescu's contribution to the development of legal education at the University of Iaşi is essential. A French legal expert, he was actively involved in the institutional and didactic consolidation of the Faculty of Law in its first years of operation. The fact that for a long time he did not have the status of professor shows us the difficult context in which the foundations of the university education from Iasi were laid. Through his works Gheorghe Mârzescu is the founder of the scientific study on civil law at the University of Iași. He was a follower of liberal values and a constant promoter of the principle of laicization, which is why he openly came into conflict with the representatives of the Church. Despite this complexity, the life and work of Professor Gheorghe Mârzescu are less well known today, often being mistaken for his son, an important politician at the beginning of the interwar period. This article aims to bring back to life some of the complex valences of this personality, emphasizing its founding role and the vocation of freedom that he has permanently promoted.
\end{abstract}

Keywords: history of legal education, civil law, academic personality 


\section{LE PROFESSEUR GHEORGHE MÂRZESCU ET LA VOCATION À LA LIBERTÉ. REGARDS SUR UN PROFESSEUR OUBLIÉ DE LA FACULTÉ DE DROIT DE L'UNIVERSITÉ DE IAȘI}

Résumé : La contribution du professeur Gheorghe Mârzescu au développement de l'enseignement juridique à l'Université de Iaşi est essentielle. Juriste de formation française, il s'est impliqué de manière active à la consolidation institutionnelle et didactique de la Faculté de Droit pendant ses premières années de fonctionnement. Le fait que, pour une longue période, il n'a plus eu la qualité de professeur nous montre le contexte difficile dans lequel ont été mis les fondements de l'enseignement universitaire de Iași. Grâce à ses ouvrages, Gheorghe Mârzescu se fait remarquer comme le fondateur de l'étude scientifique du droit civil à l'Université de Iași. Il a été adepte des valeurs libérales et un promoteur constant du principe de la laïcisation, raison pour laquelle il est entré ouvertement en conflit avec les représentants de l'Église. Malgré leur complexité, la vie et l'œuvre du professeur Gheorghe Mârzescu sont actuellement peu connues. Il est souvent confondu avec son fils, important homme politique au début de l'entre-deux-guerres. Le présent article se propose de remettre en lumière une partie des facettes complexes de cette personnalité et insiste sur son rôle fondateur et sur la vocation de la liberté qu'il a promue en permanence.

Mots-clés : histoire de l'enseignement juridique, droit civil, personnalité académique. 


\section{Cuprins}

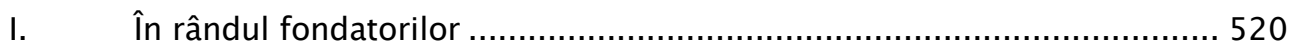

II. Deschizător de drum în studiul Dreptului civil .................................... 526

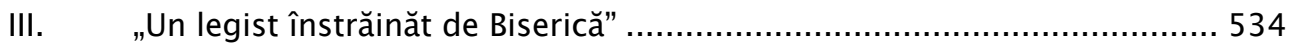

IV. În loc de concluzii.................................................................... 539

„Dar ce n-a fost Gheorghe Mârzescu ?” se întreabă retoric și totodată admirativ un autor care a evocat personalitățile din trecut ale Iașilor ${ }^{1}$, având în vedere calitățile acestuia de profesor, avocat, ziarist și om politic (deputat, senator, ministru al Cultelor și Instrucțiunii Publice). În ciuda acestei celebrități, care s-a prelungit încă mulți ani după moarte (1901), personalitatea lui Gheorghe Mârzescu este astăzi puțin cunoscută el fiind adesea confundat cu fiul său, important om politic de la începutul perioadei interbelice. O scurtă privire a activității și operei lui Gheorghe Mârzescu ne arată însă că întinderea umbrei uitării peste acest personaj ar fi o greșeală. Practic nu a existat acțiune, plan sau dezbatere majoră în societatea românească din a doua jumătate a secolului al XIX-lea în care acesta să nu fie implicat activ. De la rolul său de fondator al învățământului dreptului civil la Universitatea din Iași și până la implicarea sa în viața socială și culturală întreaga activitate a lui Gheorghe Mârzescu se desfășoară în egală măsură sub semnul pioneratului și a excelenței. Dar ceea ce impresionează în cel mai înalt grad la personalitatea

${ }^{1}$ Radu Şuțu, Iașii de odinioară, Ediție revăzută, Prefață, postfață, ediție îngrijită, selecția textelor și note de Radu Negrescu-Șuțu, București, Corint Books, 2015, p. 115. 
lui Gheorghe Mârzescu este afirmarea constantă a unor principii și valori, dintre care cea mai frecventă este cea a libertății.

\section{I. În rândul fondatorilor}

Inaugurarea Universității din Iași s-a făcut într-o ceremonie fastuoasă în ziua de 26 octombrie 1860, în prezența Domnitorului Alexandru Ioan Cuza şi a membrilor Guvernului. Programul oficial a început în dimineața zilei cu o slujbă religioasă la Biserica Talpalari (considerată biserica școlilor din Iași), continuând cu deplasarea întregului cortegiu (format din reprezentanți ai autorităților municipale și centrale, profesori ai școlilor din Iași, artiști dramatici, tipografi și librari, studenții și profesori ai facultăţilor) spre Aula Universității.

După oficierea slujbei de sfinţire de către Episcopul Filaret Scriban a urmat citirea Ordonanței Domnești de către Mihail Kogălniceanu, primministru al Moldovei și ministrul interimar al Cultelor și Instrucțiunii Publice. În baza acestui act Universitatea era organizată ca „persoană juridică cu dreptul de a se administra de sine, în cauzele atât științifice cât și disciplinare”(art. 1) având patru facultăți („filosofică, juridică, teologică și medicală”) în cadrul cărora „învățătura va fi gratuită, liberă și în limba română” (art. 2). Consiliul Academic al Universității era compus din „profesorii în activitate ai tuturor facultăților, precum și din cei retrași, care ar fi făcut serviciul școlar în vreo facultate curs de zece ani, cu titlu de membri onorari” fiind prezidat de Rector care „se alege pe fiecare an de către profesorii facultăților și din sânul lor și se recomandă prin Ministerul de Culte și Instrucțiune publică întăririi Domnești” (art. 3). Totodată, ordonanța 
prevedea că Universitatea este singura care are „dreptul și prerogativa de a conferi gradele şi onorurile academice cele mai înalte în diferite științe, precum doctoratul, diploma de magistru etc.”și că „,̂n viitor nici un june nu va mai putea fi primit în serviciile publice ale Statului, de nu va fi înzestrat cu testimoniile sau diplomele necesare, conform cu natura postului ce va ocupa"(art. 8)².

La finalul citirii Ordonanței Domnești s-a procedat la înmânarea de către Domnitor a însemnelor oficiale (sigiliul, sceptrele, drapelul, ordonanța domnească) către trei profesori ai Universități, toți de la Facultatea Juridică : Petru Suciu, Ioan Strat și Octav Teodori3

După acest moment solemn de la tribuna oficială ia cuvântul un alt profesor al Facultății Juridice, care în urmă cu două săptămâni își inaugurase cursul de Drept civil. Tânăr, ceremonios, cu o figură impozantă4 el prezintă mesajul de mulțumire din partea corpului profesoral către Domnitorul Alexandru Ioan Cuza. Numele acestui profesor este Gheorghe Mârzescu și desemnarea sa pentru transmiterea acestui mesaj avea o semnificație aparte. El făcea parte din categoria profesorilor tineri ai Universității, fără legătură cu

2 Istoricul învățământului superior din Iaşi cu date statistice până în 1895, în Anuarul Universității din Iaşi pe anul școlar 1895-1896, precedat de o ochire retrospectivă asupra învăţământului superior din Iaşi, Iași, Tipografia Națională, 1896, pp. 40-41.

3 Inaugurarea Universităţii din Iaşi în George Mârzescu, Scrieri diverse, Tomul I, București, Tipografia Curții, 1881, pp. 28-36.

4 Imaginea profesorului Gheorghe Mârzescu ne este cunoscută din descrierile contemporanilor și mai ales din portretul aflat în galeria Muzeului Universității „Alexandru Ioan Cuza” din Iași. Acest portret, pictat în anul 1909, la opt ani de la moartea lui Mârzescu, de către pictorul N. Craft, ne arată figura unui bărbat matur, cu o expresie uşor serveră „ornată” , după moda timpului, cu favoriți impozanți. Pentru detalii a se vedea Sorin Iftimi, Considerații privitoare la galeria de portrete a Muzeului Universității din Iași, în „Historia Universitatis Iassiensis”, nr. I, 2010, pp. 201-237. 
învățământul juridic organizat în baza Așezământului pentru reorganizarea învățăturilor publice sancționat de Domnitorul Grigore Alexandru Ghica în prima zi a anului 1851 .

Corpul profesoral al Facultăţii Juridice înființată, în condiții extrem de dificile, în toamna anului 1855, era format în mare parte din profesori ardeleni, precum Simion Bărnuțiu, Alexandru Papiu-Ilarian sau Petru Suciu, cu studii universitare în spațiul austriac sau italian. Singurul profesor care avea studii universitare la Paris era Teodor Veisa ${ }^{5}$, titularul cursului de Drept civil, el încercând să promoveze un curent francofil în cadrul școlii de drept ieșene ${ }^{6}$.

Gheorghe Mârzescu făcea parte din categoria „stipendiaților”, adică a tinerilor studioși trimiși pe cheltuiala statului moldovean pentru aprofundarea studiilor juridice în capitala Franței. Întorşi în țară acești tineri urmau să fie principalii contribuitori la efortul de consolidare a învăţământului public, a magistraturii sau administrației de stat. Așadar, o categorie cu un statut extrem de onorant, evidențiată de Mihail Kogălniceanu, ministrul al Instrucțiunii Publice, în raportul său adresat Domnitorului cu privire la înființarea Universității din Iași : „tinerii noștri stipendiști, pe care țara în tot anul îi trimite la Universități străine, astăzi au început a ne

5 Constantin C. Angelescu, Un jurist moldovean uitat: Teodor Veisa, Extras din „Dreptul”, nr. 27-28, 1938, Bucureşti, Tipografia „Cuvântul românesc”, 1938, pp. 3-19.

${ }^{6}$ Până la Unirea Principatelor aproximativ 11 tineri români obținuseră și doctoratul în Drept la Paris, majoritatea din Țara Românească: Petre Manega (1820), Dumitru Gr. Filipescu (1833), Dumitru Mavrocordat (1847), Gheorghe Costaforu (1850), Constantin Bosianu (1851), Vasile Boerescu (1857), Gheorghe Grigore Cantacuzino (1858), Dumitru Paul Vioreanu (1858), Constantin Darvaris (1859), Gheorghe I. Vernescu (1860), Aristide Pascal (1860). Pentru detalii a se vedea Constantin C. Angelescu, Cei dintâi români doctori în Drept de la Paris, Extras din „Dreptul”, Nr. 28 şi 29 din 1928, Fundaţia Culturală Regele Mihai I, 1928, pp. 4-26. 
reveni ; și profesori, ei plătesc prin cursurile lor sacrificïle ce țara făcut cu dânșii, odată elevi”.

Gheorghe Mârzescu nu doar că făcea parte din această categorie dar se profila ca liderul generației sale. Teza lui de licență, susținută la Facultatea de Drept din Paris în data de 17 noiembrie 1858 sub coordonarea profesorului Joseph Ortolan, a fost publicată în același $a^{8}{ }^{8}$. După modelul vremii ea cuprinde două părți : prima dedicată unei instituții juridice din dreptul roman (De jurejurando, sive voluntario, sive necessario, sive judiciali), iar a doua dedicată unor instituții din dreptul francez (De la preuve des obligations et de celle du paiement; Des achats et ventes). Vacantarea catedrei de Drept civil, prin plecarea profesorului Teodor Veisa, i-a permis preluarea acestui curs fundamental, moment marcat prin susținerea unei prelegeri în fața studenților, profesorilor și a mai multor notabilități ale orașului.

Discursul din data de 26 octombrie 1860 s-a fundamentat pe ideea că instrucțiunea publică este „bază a libertăţii, independenței, liniștii și prosperității popoarelor”, astfel că „după cum ea este mai mult sau mai puțin răspândită în cercul unui popor, pe atât se și zice că acel popor are conștiință de existența, libertatea și neatârnarea sa”. Când popoarele reclamă o libertate mai mare ?, se întreabă în mod retoric Mârzescu. „Când iată se găsesc mai luminate !”, mărturisind credința sa că „fără de lumină nu poate exista libertate" 9 .

Peste o lună de zile de la acest moment, Gheorghe Mârzescu revine în atenția generală în contextul tensiunilor privind alegerea rectorului

${ }^{7}$ Istoricul învățământului superior din Iași cu date statistice până în 1895..., p. 47.

${ }^{8}$ G. Marzeskou, Thèse pour la licence, Paris, Typographie et lithographie Lacour, 1858, p. 79.

9 Inaugurarea Universității din Iaşi..., pp. 32-35. 
Universității. Inaugurarea fastuoasă a noului așezământ universitar nu a fost urmată, aşa cum era firesc, și de alegerea imediată a reprezentantului legal deoarece Facultatea de Medicină nu era înființată și, în consecință, procesul de constituire al Universităţii nu putea fi considerat finalizat. În prima ședință a Consiliului Academic, din data de 28 octombrie 1860, profesorul Petru Suciu a susţinut că Universitatea are personalitate juridică și deci trebuie să se aleagă Rectorul, dar această opinie a rămas minoritară ${ }^{10}$.

Printre cei care invocau imposibilitatea alegerii Rectorului în lipsa profesorilor Facultății de Medicină se afla și Gheorghe Mârzescu, dar la şedinţa Consiliului Academic din data de 24 noiembrie 1860 el și-a reconsiderat poziția în termenii următori: „Adaug totodată de a zice că am fost cel dintâi în Consiliu care am propus să nu procedăm la alegerea Rectorului, până la numirea prin Ordonanță Domnească a profesorilor de la Medicină. Martori la aceasta îmi sunteți domniile voastre toți. Afirm aceasta pentru ca domnii medici să nu socotească mai târziu că am arătat mai puțină deferență pentru această ramură a Institutului Universitar. Însă, d-lor, am zis și am repetat-o chiar în ședința trecută că de o lună așteptăm pentru ca și Facultatea de Medicină să fie reprezentată în Consiliul Academic, și din cauză că nu suntem deplin constituiți, că nu avem pe reprezentantul nostru suprem, că Consiliul Academic nu-și are Rectorul său, exercițiul drepturilor concedate prin Statute e paralizat. Să procedăm, deci, la alegerea Rectorului, căci odată el numit, ales din sânul nostru, sancționat de Domn, el nu va lipsi de a lua măsurile necesare, de a dărui și mijloci ca și facultatea de Medicină să se

\footnotetext{
10 Cătălin Botoșineanu, Alegerile pentru funcția de rector și evoluția demnității rectorale, în Gheorghe Iacob, Alexandru-Florin Platon (coordonatori), Istoria Universităţii din Iași, Iași, Editura Universității „Alexandru Ioan Cuza”, 2010, p. 428.
} 
constituie cât mai curând și astfel să-și înceapă cursul său. Căci, d-lor, Rectorul este custodele drepturilor concedate prin actul de fundare a Universităţii!"11.

Această opinie fiind agreată de majoritatea participanţilor discuțiile au continuat cu privire la persoana care ar fi trebuit să-și asume această onorantă sarcină. Primul gând a plecat către Simion Bărnuțiu, în virtutea experienței sale în dezvoltarea învățământului superior și a prestigiului de care se bucura în mediul academic ieșean. Acesta a refuzat însă propunerea făcută într-un mod insistent tot de către Gheorghe Mârzescu, arătând că nici măcar nu va participa la vot deoarece el și ceilalți profesori ardeleni participanți la ședința Consiliului Academic din 24 noiembrie 1860 (Ștefan Emilian și Ion Popa) sunt supuşi austrieci. În aceste condiții, cu votul unanim al celor 7 profesori care au votat, a fost ales Rector al Universității din Iași un alt profesor al Facultăţii Juridice, Ioan Strat, care de la începutul lunii noiembrie 1860 era decanul acestei facultăţi ${ }^{12}$.

Atitudinea principială a lui Gheorghe Mârzescu, în considerarea libertăţii şi a demnităţii pe care le promova insistent, l-a adus pe acesta în mijlocul unui conflict instituțional care s-a soldat cu demisia unei mari părți a profesorilor Universității şi chiar a rectorului ales. În ianuarie 1862 ministrul Cultelor și Instrucțiunii, Al. Cantacuzino, a numit la direcția Școlii Centrale de Fete o persoană din anturajul său de familie. Numirea a fost surprinzătoare și fără acordul Consiliului Școlar, organism care gestiona politica de dezvoltare a educației publice din Moldova încă dinainte de

${ }^{11}$ Alegerea primului Rector al Universității din Iași, în George Mârzescu, Scrieri diverse, Tomul I, București, Tipografia Curții, 1881, pp. 38-39.

12 Victor Slăvescu, Ion Strat. Economist, financiar, diplomat. !836-1879, vol. I, București, Imprimeria Națională, 1946, p. 13. 
momentul Unirii. La protestul argumentat al membrilor Consiliului Școlar, ministrul Cantacuzino a răspuns total neinspirat prin demiterea a trei membri ai consiliului, printre care și Gheorghe Mârzescu ${ }^{13}$. Acesta a fost momentul în care conflictul a escaladat ajungându-se la demisia majorităţii profesorilor şi a rectorului Strat, în ianuarie 1862, și perpetuarea unei situații de incertudine cu privire la funcționarea Universității care s-a extins până la momentul alegerii ca rector a profesorului Titu Maiorescu, la data de 18 septembrie 1863.

\section{Deschizător de drum în studiul Dreptului civil}

Prin prelegerea din data de 9 octombrie 1860 Gheorghe Mârzescu a inaugurat un curs universitar dar a pus și bazele unei metode de studiu asupra dreptului civil. Deși își rezervă un rol modest, acela de profesor chemat la catedră pentru „a vă explica codul civil”14, el insistă de la început pe importanța cunoașterii principiilor dreptului natural: „În studiul materiilor științei noastre mă voi sili de a va înrădăcina în minte principiile fundamentale, această bază necesară oricărui studiu serios şi solid, principiile fundamentale ce domină pe fiecare din ele. Statornica mea îngrijire nu va fi numai de a vi le înrădăcina bine în minte, ci și a le disciplina și a le clasa în ordinea ce mi se va părea mai clară și mai rațională. Vă voi arată consecințele acestor principii, apoi dificultățile ce se pot naște și care pot să dea loc la

13 Florea Ioncioaia, Înființarea și începuturile Universităţii (1860-1864), în Gheorghe Iacob, Alexandru-Florin Platon (coordonatori), Istoria Universității din Iași, Iași, Editura Universității „Alexandru Ioan Cuza”, 2010, p. 143.

14 Discursul rostit la deschiderea cursului de drept civil în Facultatea Juridică din Iași (9 octombrie 1860), în George Mârzescu, Scrieri diverse, Tomul I, București, Tipografia Curții, 1881, p. 3 . 
deosebite sisteme. Neîncetat vom avea sub ochi legea pozitivă, adică legea formulată de legiuitorul pământesc și pe care cu toată critica ce va merita, noi vom respecta, noi vom trebui a o respecta și a ține socoteala de dânsa până în moment ce legislatorul o va înlocui prin legea conformă tipului dreptății, vreau să zic a dreptului natural. Căci o lege nu este bună întrucât ea nu este formula dreptului natural. Acela este un bun legiuitor care știe să formuleze principiile cerute de rațiune, adică principiile dreptului natural, ce este culmea pe care neîncetat trebuie să se urce legiuitorul fără însă ca vreodată să poată ajunge la vârf"15.

Codul civil pe care îl preda la acel moment Gheorghe Mârzescu era Condica civilă a Moldovei, cod adoptat în anul 1817 din porunca Domnitorului fanariot Scarlat Callimach. Fără a diminua valoarea acestui monument legislativ, Gheorghe Mârzescu lansează o perspectivă critică în care principalul element de vulnerabilitate îl reprezintă lipsa unei sistematizări logice. Din acest motiv, el și propune expunerea materiei „întrun chip rațional”, în care fără a neglija metoda exegetică, nu va uita că este „însărcinat cu un curs de cod civil, ceea ce-mi impune îndatorirea de a interpreta, de a explica codul civil considerat ca lege în viață, ca lege aplicabilă şi obligatorie"16.

Principale direcții de cercetare enunțate în această lecție inaugurală au fost continuate într-o lucrarea publicată cinci ani mai târziu, într-un moment în care intrarea în vigoare a Codului civil Alexandru Ioan I era o certitudine. Prin Explicațiunea introducerii Codului civil se realizează, pentru prima dată în doctrina civilistă românească, o punte între reglementarea fanariotă,

15 Ibidem, pp. 16-17.

${ }^{16}$ Ibidem, p. 20. 
influențată de Codul civil austriac din anul 1811, și noul Cod civil aflat sub hegemonicul model al Codului civil napoleonian. Gheorghe Mârzescu îşi asumă sarcina prezentării acestei tranziții arătând în Prefața lucrării, că o parte considerabilă a explicațiilor sale vor fi utile și pentru noua reglementare deoarece „cartea mea nu-i decât o compilație și câte odată chiar o traducere din cei mai buni profesori și autori francezi, cum sunt Demolombe, Oudot, Marcadé, Troplong, Mouroln, Esbach, etc.. etc." ${ }^{17}$. Se deschide astfel calea imitației masive a doctrinei juridice franceze, ca un reflex al transplantului legislativ, care va caracteriza doctrina juridică românească, cu predilecție cea de drept civil, până la începutul secolului al XX-lea.

Gheorghe Mârzescu a rămas fidel dreptului civil întreaga sa viață, chiar și în perioada în care întrerupându-și activitatea la catedra de drept civil a Facultății de Drept din Iaşi (1864-1881) şi-a semnat lucrările ca „avocat pe lângă Curtea de Apel din Iași” și „fost Profesor de Codice Civil”18. Având conștiința propriei sale valori a răspuns, cel mai adesea în mod ironic, celor care îi minimalizau importanța lucrărilor științifice: „Știu c-am rămas înapoi în ştiința Dreptului de foștii mei camarazi de studiu, unii dintre ei învăţaţi și distinși profesori, iar alții înalți magistrați. Îi rog, însă, să fie indulgenți către mine; căci le promit că mă las de publicațiuni juridice în ziua când îi voi vedea că se pun dânșii a da publicității lucrarea inteligenței și a mâinilor lor. Nu cer volume groase, căci spre a merita numele de marele jurisconsult nu cred să fie necesare volume de mii de pagini. Este de ajuns să fie aruncată în știința

17 George Mârzescu, Explicațiunea introducerii Codului civil precedată de introducere generală în studiul dreptului, Iași, Tiparul Tribunei Române, 1865.

18 George Mârzescu, Apărarea Societății de aprovizionare a Armatei Imperiale Active Ruse A. Horwitz, E. Gregher și A. Cohan dinaintea Curții de Apel din București, Secțiunea I, București, Tipografia Curții, 1878. 
Dreptului o sămânță utilă, care germinând să producă fructe utile. Știu că se poate întâmpla ca omenirea gustând din aceste fructe nemuritoare ea nici să mai cerceteze numele oamenilor care i le-a procurat, întocmai cum fac și femeile acele care împodobindu-se cu pietre prețioase, nu se gândesc niciodată la acei care se afundă în ocean spre a scoate acele pietre prețioase cu pericolul vieții lor"19.

În perioada în care nu a mai avut calitatea de profesor preocupările sale științifice au luat forma unor studii dedicate unor subiecte controversate sau abordate nesatisfăcător în doctrină, dintre care două prezintă o semnificație deosebită: Le Code Cousa devant la religion et la famille (1865) și Efectul testamentelor și donațiunilor între vii, făcute sub imperiul Codicelui Civil Calimachi, în ceea ce se atinge de legitimă sau rezervă în cazul în care testatorul sau donatorul moare sub imperiul Codicelui civil actual (1870).

Primul text reprezintă critica formulată de Gheorghe Mârzescu împotriva modului de reglementare al dreptului de succesiune al copiilor naturali în Codul civil Cuza. În acest aspect legea românească s-a îndepărtat de modelul francez, care recunoștea șase clase de copii (copii legitimi, copii legitimați, copii naturali simpli, copii naturali adulterini, copii naturali incestuoși, copii adoptivi), reglementând o singură categorie, cea a copiilor naturali. Din interpretarea articolelor 652 și 657 ale Codului intrat în vigoare în anul 1865 rezulta că la succesiunea mamei, ascendenților și colateralilor mamei erau chemați în mod egal cu copiii legitimi nu doar copiii naturali

19 G. Mârzescu, Maximele dreptului roman cu aplicațiuni la Codicele nostru civil, Partea I, Iași, f.e., 1880, pp. XX-XXI. 
simpli ci şi cei adulterini şi incestuoși ${ }^{20}$. Această asimilare a fost considerată de către Mârzescu drept „imorală și revoltătoare”21, criticând faptul că „,acest prunc fraged [Codul civil român n.a.] a cutezat, în contra principiilor solide ale tatălui său, adică ale Codicelui Napoleon"22.

$\mathrm{Cu}$ această concluzie radicală studiul nu a putut fi publicat, deși fusese imprimat la tipografia „Buciumul Român” din Iași, atât tipografia cât și autorul fiind avertizați de prefectul districtului Iași, Nicu Catargiu, că vor urma represalii judiciare. Ceea ce a urmat este un episod inedit în știința juridică românească: textul studiului a fost publicat la Paris, în limba franceză, sub semnătura lui Nicolae Roset Rosnovanu care recunoaște în prefață că „unul din amicii noștri, unul din cei mai renumiți avocați ai baroului nostru, a binevoit să ne comunice scrierea pe care o publicăm astăzi, scriere dictată de aceleași simțăminte, de aceeași indignare”23. În anul 1881 textul a fost republicat în România, de data aceasta cu numele autorului, împreună cu istorisirea acestei întâmplări ciudate.

Cel de-al doilea studiu are în vedere o problemă cu o mare incidență practică dar care nu beneficia nici în doctrină și nici în jurisprudență de o interpretare unitară. Gheorghe Mârzescu analizează toate aceste abordări contradictorii și reușește să „dezlege” problema de drept prin aplicarea principiilor fundamentale ale dreptului civil. În Prefața acestui studiu el justifică această tehnică de interpretare arătând și terenul arid pe care vine cercetarea sa: „Consultați în mai multe rânduri asupra acestei materii atât de

\footnotetext{
${ }^{20}$ Despre dreptul de succesiune a copiilor naturali după Codicele civil Alexandru Ioan Cuza în George Mârzescu, Scrieri diverse, Tomul I, București, Tipografia Curții, 1881, p. 115.

${ }^{21}$ Ibidem, p. 116.

22 Ibidem, p. 105.

23 Ibidem, p. 89.
} 
delicate și de importante credem, în lipsă de comentarii de drept scrise în limba română, că facem un adevărat serviciu atât concetățenilor cât și magistraților noștri, dând publicităţii după cei mai eminenți jurisconsulți adevăratele principii ce cârmuiesc materia aceasta şi pe care principii noi am avut deja ocazia de a le pune în vedere atât amicilor cât și clienților ce ne-au făcut onoarea de a ne consulta în privința aceasta. Chestiunea de faţă este, putem să zicem, de o utilitate cotidiană în privire că abia numai de câțiva ani noi trăim sub imperiul noului Cod și astfel pe fiecare zi tribunalele sunt puse în poziția de a judeca testamentele și donațiile între vii făcute sub imperiul Codul Callimach. A ignora, deci, asupra materiei aceasta adevăratele principii este a răpi drepturi câștigate și, în consecință, a viola principiul scris pe frontispiciul Codului civil: «Legile nu au efect retroactiv»" 24 .

În anul 1880 Gheorghe Mârzescu a publicat o lucrare, inedită pentru literatura juridică românească de până atunci, în care a explicat actualitatea unor reguli din dreptul roman prin raportare la dispozițiile contemporane ale dreptului civil românesc. Ataşamentul civilistului Gheorghe Mârzescu pentru cunoașterea aprofundată a dreptului roman era cunoscut încă de la debutul carierei sale. În lecția introductivă a cursului de Drept civil, din data de 9 octombrie 1860, el anunța că „neîncetat vom alerga la dreptul roman, ce este baza științei noastre, baza tuturor legislațiilor moderne. Mă voi sili de a vă face cunoscute, prin urmare, clare toate legile romane ce au trecut în dreptul nostru pozitiv sau de care a fost însuflețit legiuitorul când a prescris cutare sau cutare măsură. Vom avea astfel a ne întreba despre diferențele din codul

24 Gheorghe Mârzescu, Efectul testamentelor și donațiunilor între vii, făcute sub imperiul Codicelui Civil Calimachi, în ceea ce se atinge de legitimă sau rezervă în cazul în care testatorul sau donatorul moare sub imperiul Codicelui civil actual, Iași, Tipografia Societății Junimea, 1870, Prefață. 
nostru civil cu legile romane privitoare la același obiect. Prin chipul acesta numai se poate asigura cineva de gradul la care a pătruns o materie"25.

Două decenii mai târziu el publică Maximele dreptului roman cu aplicațiuni la Codicele nostru civil, o lucrare proiectată în patru părți: Partea I - Regulile generale atât de drept natural cât și de drept civil; Partea a II-a - Maximele privitoare la persoane; Partea a III-a - Regulile privitoare la lucruri; Partea a IV-a - Aforismele relative la acțiuni și decizii judiciare. Din păcate, nu a reuşit să publice decât un singur volum, corespunzător primei părți, un astfel de proiect nemaifiind reluat vreodată în literatura juridică românească.

În anul 1881 Gheorghe Mârzescu revine la catedra de Drept civil a Facultății de Drept din Iași rămasă vacantă din cauza bolii profesorului Vasile Conta, care în anul următor va deceda la vârsta de 36 de ani ${ }^{26}$. Doi ani mai târziu revine și în plan științific cu o lucrare de forță: Căsătoria. Studiu comparativ. După dreptul civil, dreptul canonic şi dreptul civil internațional. Această lucrare, proiectată în mai multe volume, era gândită ca debutul unei serii de studii de legislație comparată în care să fie analizate cele mai importante instituții ale dreptului civil ${ }^{27}$. A fost publicată doar prima

25 Discursul rostit la deschiderea cursului de drept civil în Facultatea Juridică din Iași (9 octombrie 186o)..., pp. 17-18.

${ }^{26}$ Anuarul Universității din Iași pe anul școlar 1895-1896, precedat de o ochire retrospectivă asupra învățământului superior din Iași, Iași, Tipografia Națională, 1896, p. 54. Anterior venirii lui Vasile Conta la Universitatea din Iași, în anul 1873, cursul de Drept civil a fost predat la Facultatea de Drept din Iași de către Nicolae Mandrea, magistrat și junimist, care a făcut în aceste calități obiectul unor ironii acide din partea lui Gheorghe Mârzescu.

27 Interesul lui Gheorghe Mârzescu pentru legislația comparată se observă și din publicarea în limba română a unor studii ale unor juriști occidentală la care a adăugat o serie de comentarii cu relevanță pentru dreptul românesc: Studiu analitic asupra Codicelor Annamiților și Chinezilor, în George Mârzescu, Scrieri diverse, Tomul I, București, Tipografia Curții, 1881, pp. 
parte a volumului dedicat căsătoriei în care este prezentat istoricul instituției şi sunt analizate dispozițiile constituționale și legale, precum și principalele orientări jurisprudențiale. Ideea centrală a studiului se fundamentează pe principiul laicizării instituției căsătoriei, ceea ce îi permite lui Gheorghe Mârzescu să se lanseze într-o savuroasă dispută cu textele oficiale ale Bisericii Ortodoxe Române. De altfel, volumul are ca subtitlu Cu o canonică critică la adresa Sfântului Sinod pentru memoriul: Papismul și starea actuală a Bisericii Ortodoxe în Regatul României, cu referire la două documente ecleziastice pe care Mârzescu le prezintă, în stilul caracteristic, „doi îngrozitori balauri” care „atacă și chiar insultă, prin unele fraze, societatea laică” și disprețuiește „libera cugetare, podoaba exclusivă dată numai omului cuvântător și înțelegător”28.

Ultima etapă a vieții și a carierei academice a profesorului Gheorghe Mârzescu se va petrece la Universitatea din București unde va ocupa, începând cu anul 1896, catedra de Drept civil29. Din această poziție el publică şi cea mai importantă lucrarea didactică a sa, un manual universitar în două volume întitulat Curs de drept civil (1899-1900).

150-216; Principii de drept internațional privat asupra căsătoriilor dintre privați și dintre familiile regale, asupra divorțului și a succesiunilor, în Ibidem, pp. 367-473.

${ }^{28}$ George Mârzescu, Căsătoria. Studiu comparativ. După dreptul civil, dreptul canonic și dreptul civil internațional, Partea I-a, Cu o canonică critică la adresa Sfântului Sinod pentru memoriul: Papismul și starea actuală a Bisericii Ortodoxe în Regatul României, Iași, Tipografia Națională, 1883, pp. III-IX.

${ }^{29}$ Anuarul Universităţii din Bucureşti pe anul şcolar 1900-1901, Bucureşti, Institutul de Arte Grafice „Carol Göbl”, f.a., p. 19. 
III. „Un legist înstrăinăt de Biserică”

Orice evocare a personalităţii lui Gheorghe Mârzescu nu poate face abstracție de cariera sa de avocat. Spiritul său liber și atitudinile sale neconformiste s-au manifestat într-o măsură mai accentuată în dezbaterile din pretoriu decât în amfiteatru. Între cele două forme de exprimare există însă și o legătură directă manifestată prin faptul că, după obținerea soluției judiciare, Gheorghe Mârzescu și-a publicat cele mai importante pledoarii. Găsim astfel în paginile acestor broșuri nu doar descrierea unor situații de fapt cu o mare rezonanță în societatea vremii dar și o solidă argumentație științifică pentru opiniile susținute.

Primul proces de rezonanță în care a intrat a fost cel în care l-a apărat pe Titu Maiorescu, rectorul Universităţii din Iaşi, împotriva acuzelor aduse prin intermediul ziarului „Tribuna”, aparținând lui Nicolae Ionescu, de comportament imoral în poziția de profesor de gramatică la Școala Centrală de Fete din Iași. Mai precis i se imputa lui Titu Maiorescu faptul că ar fi avut o idilă cu Emilia Ricquert, guvernantă în cadrul aceluiași aşezământ școlar. Acuzația a stârnit multe ironii, fiind considerată frivolă în societatea ieșeană, însă Parchetul a început o anchetă penală. În cadrul procesului desfăşurat în fața Tribunalului Iași, în primăvara anului 1865, Gheorghe Mârzescu reușește să demonstreze că acuzație este o calomnie, pornită din ura viscerală a unui grup de profesori universitari (Nicolae Ionescu, Ştefan Micle, Grigore Cobălcesu) împotriva rectorului Titu Maiorescu. La principalul argument al adversarilor că „nu iese fum fără foc”, Mârzescu a dat un răspuns care a rămas multă vreme în memoria protipendadei ieșene: „După legile Naturii nu este 
neapărat trebuință ca să fie foc pentru ca să iasă fum. Fumul iese și din gunoi. Probă procesul de față!”3o.

O categorie importantă a litigiilor în care a pledat Gheorghe Mârzescu este cea a delictelor de presă, adică a proceselor în care redactorii diferitelor publicații erau trimiși în judecată penală sub acuza unor articole calomnioase față de Rege și politica guvernamentală. Materia era una foarte sensibilă pentru că punea în discuție starea libertății presei în societatea românească și genera pericolul unor represalii, cel puțin de natură politică, împotriva apărătorilor.

La data de 18 martie 1872 s-a desfăşurat în fața Curții cu Jurați din Roman procesul penal în care Alexandru Beldiman, proprietar şi redactor al ziarului „Adevărul” din Iaşi, era inculpat pentru delict de presă constând în ofense și calomnii aduse Domnitorului Carol I şi subminarea ordinii constituționale. Acuzațiile porneau de la patru articole, apărute în decembrie 1871 și ianuarie 1872 , prin care se nega dreptul la succesiune la tron în familia Domnitorului și se susținea lipsa de loialitate a lui Carol I față de statul român. Formulate în această manieră acuzațiile au dat impresia unui proces cu rezonanță istorică, juriul fiind format din mai multe personalități din Moldova printre care și poetul Vasile Alecsandri care avea calitatea de primjurat. Gheorghe Mârzescu nu a fost singurul apărător al ziaristului Alexandru Beldiman, Parchetul chiar vorbind de un veritabil „Consiliu de Apărare”, însă prin pledoaria sa a susținut cu argumentele cele mai puternice nevinovăția acestuia. Afirmând în mod solemn că „astăzi nu este procesul lui Alecu Beldiman, redactorul ziarului Adevărul dar este, lucru înspăimântător!

$3^{\circ}$ G. Mârzescu, Apărarea dinaintea Tribunalului din Iaşi, Secțiunea a II-a a D-lui Titu Livie Maiorescu, Iaşi, Tipografia Buciumul Român, 1865, p. 14.

535 
procesul drepturilor și libertăţilor constituţionale consfinţite prin pactul nostru fundamental”31, el a arătat că recunoscând principiul inviolabilităţii persoanei Domnitorului „națiunea nu poate renunța și abdica nici într-un caz la drepturile ei naturale și imprescriptibile" ${ }^{2}$. In consecință, prin exprimarea criticilor sale, ziaristul Beldiman nu a urmărit ofensarea Domnitorului ci și-a făcut datoria de cetățean apărând Constituția „contra tuturor vrăjmașilor, fie mari, fie mici”33.

Dar procesul care pune în lumina cea mai puternică personalitatea complexă a lui Gheorghe Mârzescu este cel în care l-a apărat pe arhiereul Calistrat Orleanu împotriva hotărârile Sinodului Sfintei Biserici Autocefale Ortodoxe Române. Spre deosebire de procesele mai sus-amintite, acesta nu a fost câștigat de avocatul Gheorghe Mârzescu fiind admisă excepția de necompetență a Curții de Casație invocată de Procurorul General, însă el poate fi considerat cel mai important prin prisma valorilor pe care le-a afirmat în susținerea apărării: libertatea conștiinței, secularizarea și suveranitatea națională. În nici într-o pledoarie nu se observă într-o manieră atât de evidentă cultura impresionantă a lui Mârzescu, atenția dată fiecărui argument și, mai ales, spiritul său liber de orice constrângere formală. De altfel, în fața mustrărilor din partea ierarhilor Bisericii că are o atitudine duşmănoasă și că a devenit „un legist înstrăinat de Biserică” el răspunde afirmându-și libertatea de conștiință: „Nu pentru prima oară în cariera mea de avocat prelații, persecutați de Sinod, au făcut apel la mine, ca să atac fărădelegile comise de

${ }^{31}$ Proces de presă la Ziarul „Adevărul” înaintea juraților din Roman, în George Mârzescu, Scrieri diverse, Tomul I, București, Tipografia Curții, 1881, p. 265.

$3^{2}$ Ibidem, p. 268.

33 Ibidem, p. 284. 
Sinod și să apăr inocența îngenunchiată şi biruită de ipocrizie. Așa, în 1873, am avut distinsa onoare ca să apăr pe chiar Înalt Mitropolitul Moldovei și Sucevei Calinic Miclescu, adică tocmai pe actualul Mitropolit Primat, contra tot al acestui sfânt Sinod şi tot pentru un act nelegiuit și anticanonic săvârşit de Sinod. Prin urmare Înalții Prelați din Sfântul Sinod, acei care dacă nu mă cunosc de copil mic mă cunosc cel puțin de pe când apăram pe Mitropolitul Calinic au putut să se convingă că nu sunt om care să mă dau îndărăt, când mai cu seamă sunt profund convins de dreptatea și sfințenia unei cauze, a cărei apărare mi se încredințează! (...)"34.

În esență, în vara anului 1883 arhiereul Calistrat Bârlădeanu a fost suspendat din serviciile arhierești pentru „refuzul de a participa cu ceilalți P.S. Membri la actele sinodale”35 el refuzând să semneze o enciclică a Sfântului Sinod cu privire la situația învățământului din școlile catolice. Ulterior, începe judecata sinodală împotriva sa în care a fost acuzat că folosește texte neagreate, suprimă forme liturgice obligatorii și sădește vrajbă în rândul Bisericii. Arhiereul Calistrat a refuzat să participe la judecata sinodală și la data de 25 noiembrie 1883, prin intermediul lui Gheorghe Mârzescu, s-a adresat Curții de Casație solicitând protecție împotriva „prigonirii anticonstituționale şi anticanonice" la care este supus ${ }^{36}$.

În cadrul ședinței Secţiei a II-a a Curții de Casație din data 24 februarie 1884 Mârzescu se adresează judecătorilor cu formula „Înalt Județ de Boieri Lumeşti”, face lungi incursiuni în istoria bisericii, citează copios din scrierile

\footnotetext{
34 George Mârzescu, Apărarea arhiereului Calistrat Orleanu înaintea Înaltei Curți de Casație și de Justiție contra nelegiuirilor sinodale, București, Tipografia Academiei Române, 1884, pp. c-d.

35 Ibidem, p. IX.

${ }^{36}$ Ibidem, p. XLV.
} 
autorilor moderni și din reglementările laice și ecleziastice pentru a ajunge la o concluzie fără echivoc: „Sinodul tinde, contra Constituției, a face din biserica noastră națională o putere spirituală nesupusă controlului Statului”37. La apărarea Sfântului Sinod că sancționarea abaterilor religioase este în competența sa exclusivă, Gheorghe Mârzescu răspunde într-o manieră care nu avea cum să fie pe placul reprezentanților Bisericii: „Nu cred să se găsească un singur român drept pravoslavnic creștin, care să se oprească la scoarța cuvintelor pedeapsă spirituală, pedeapsă disciplinară, pedeapsă religioasă, și să nu zgârie acea scoarță, și plin de indignare să nu exclame: Sinodul nu este stat în stat; autoritatea lui chiar în sfera religioasă încă este supusă controlului statului, mai cu seamă când deciziile și măsurile, ce le-ar lua, deși calificate de un ordin pur religios, ar fi distrugătoare principiilor de ordine socială și de suveranitate națională" 38 .

Pledoaria se încheie în aceeași notă laicizantă cu exprimarea speranței că „acest Înalt Județ de luminați boieri lumești, plecându-se și ridicând de jos, de pe pământ, drapelul societăţilor moderne, ce a fost aruncat de d. Procuror General, va respinge excepția de necompetență și va face astfel să triumfe în Statul Român sfânta trinitate: libera cugetare, secularizare, suveranitate națională!"39.

37 Ibidem, p. 40.

${ }^{38}$ Ibidem, pp. 89-90.

39 Ibidem, p. 100. 


\section{IV. În loc de concluzii}

Conturarea unei personalități atât de complexe precum cea a lui Gheorghe Mârzescu este dificil de realizat în limitele unui articol. Aceste crochiuri nu fac decât să readucă, într-un mod parțial, în atenție activitatea, faptele și ideile unui personaj emblematic pentru procesul de modernizare al societății românești în a doua jumătate a secolului al XIX-lea. Rolul său nu este limitat doar la catedră sau în sala de judecată Gheorghe Mârzescu fiind un personaj reprezentativ pentru elita moldovenească din anii imediat ulteriori Unirii. Adept fără rezerve al procesului de unificare al celor două principate românești, el a refuzat un rol marginal implicându-se științific, profesional şi politic în construcția statului național. În ciuda acestor contribuții majore, generația din care a făcut parte Gheorghe Mârzescu, în special cea moldovenească, este neglijată, interesul cercetătorilor fiind concentrat mai ales pe realizările elitei interbelice. Această sumară evocare urmărește să acopere măcar parțial această nedreptate cu speranța că istoriografia juridică românească va cunoaște în scurt timp investigații mai amănunțite asupra acestor personalități. 